\title{
Geotechnical Investigations of Sub-Grade Soils at the Connector Road, New Tiba City, Luxor, Egypt
}

\author{
Hesham A. H. Ismaiel \\ Geology Department, Faculty of Science, South Valley University, Qena, Egypt \\ Email: heshahmed@yahoo.com
}

How to cite this paper: Ismaiel, H.A.H. (2018) Geotechnical Investigations of Sub-Grade Soils at the Connector Road, New Tiba City, Luxor, Egypt. Open Journal of Geology, 8, 1133-1145.

https://doi.org/10.4236/ojg.2018.812069

Received: August 7, 2018

Accepted: November 26, 2018

Published: November 29, 2018

Copyright $\odot 2018$ by author and Scientific Research Publishing Inc. This work is licensed under the Creative Commons Attribution International License (CC BY 4.0).

http://creativecommons.org/licenses/by/4.0/

\section{(c) (i) Open Access}

\begin{abstract}
The presented study dealt with geotechnical investigations on the sub-grade soils along the connector road between the electrical transformer station and the industrial city, New Tiba city, Luxor, to classify these soils and to examine their geotechnical behavior and their proportionality for constructing the road at the study area. One of the most important aims of this work was to determine the problematic sub-grade soils and to recommend the suitable reclamation. To achieve these goals sixty disturbed samples from six mechanical wash drilling boreholes and three undisturbed samples from three open pits were collected. The studied soils were belonged to Quaternary age. Gradation parameters (coefficient of uniformity, $\mathrm{Cu}$ and coefficient of concavity, $\mathrm{Cc}$ ), plasticity, California bearing ratio $(\mathrm{CBR})$, proctor density and free swelling percent of the studied soils were measured. $\mathrm{PH}$-value, dissolved chloride, dissolved sulfate, calcium carbonate, total carbonate, and total dissolved salts were determined. The results pointed that the studied Quaternary soils along the study road were mainly composed of gravels, sands and clayey sands. The studied gravels were classified as poorly graded gravels (GP) according to Unified Soil Classification System (USCS) and as A-1-b according to American Association of State Highway and Transportation Official (AASHTO). The studied sands were classified as well graded sands (SW) according to USCS and as A-1-a according to AASHTO. The results showed also that the sub-grades at boreholes no. 1, 3, 4, 5, and 6 were excellent to good and the sub-grade at boreholes no. 2 was fair to poor. Free swelling percent of the studied clayey sand soils was ranging from $30 \%$ to $80 \%$ and they were classified as low to medium grade expansive soil. Replacement and/or chemical stabilization (using lime and/or cement kiln dust) of the problematic clayey sands soils were suggested to reduce their swelling and to prevent the possible heave.
\end{abstract}




\section{Keywords}

Proctor Density, California Bearing Ratio, Swelling

\section{Introduction}

To solve a problem of population increase in Egypt, the Egyptian government constructs several of new cities in the western and eastern deserts and Sinai Peninsula like New Qena city, New Sohag city, New Tiba city, etc. The studied area lies at the New Tiba city which is one of these new cities. New Tiba city locates at the East of Luxor city in the eastern desert (Figure 1). Several roads are constructed at the study area to complete the infrastructures of the New Tiba city. One of the most important roads at the study area is the connector road which connects between the electrical transformer station and the industrial city. A roadway section consists of a complete pavement system [1] as shown in Figure 2. The sub-grade refers to the in situ soils on which the stresses from the overlying roadway will be distributed. The sub-base or sub-base course and the base or base course materials are stress distributing layer overlying sub-grade layer and underlying of the pavement layer. The pavement structure consists of a relatively thin wearing surface constructed over a base course and a sub-base course, which rests upon an in situ sub-grade. The present investigation deals with geotechnical behavior and engineering classification of Quaternary soils used as sub-grade soils along the connector road project at New Tiba city area.

\subsection{Previous Works}

The study area was geologically investigated by many authors such as [2]-[15], and others. Few engineering and geotechnical investigations were conducted on the studied area like engineering geophysical study to evaluate the geotechnical behavior of the soils at Tiba city [16], investigation of rock deterioration in the Royel Tomb of Seti I, Valley of The Kings, Luxor [17], engineering geophysical study at New Qena city north the study area [18], engineering classification of the soils exposed along Upper Egypt-Red Sea road north of the study area [19], geotechnical evaluation study of Pliocene sedimentary rocks exposed along Qena-Safaga road north of the study area [20], and geotechnical evaluation of the sub-grade soils at the Cemeteries area, New Tiba city [21].

\subsection{Scopes of the Present Work}

The present work is concentrated on the geotechnical behavior of the sub-grade soils of the connector road at new Tiba city to classify these soils and to determine their proportionality for constructing the road at the study area. This study focused also on an exploration of the problematic soils especially the fine grained soils to suggest the favorable treatment. 


\subsection{Geological Setting}

The study area is located about $10 \mathrm{~km}$ to the east of Luxor city and about $50 \mathrm{~km}$ to the south of Qena city. It lies between latitudes $25^{\circ} 43^{-} \mathrm{N}$ and $25^{\circ} 46^{-} \mathrm{N}$ and longitudes $32^{\circ} 45^{-} \mathrm{E}$ and $32^{\circ} 47^{-} \mathrm{E}$ (Figure 3 and Table 1 ). The area has a wide variety of sediments belonging to the Upper Cretaceous-Lower Tertiary succession

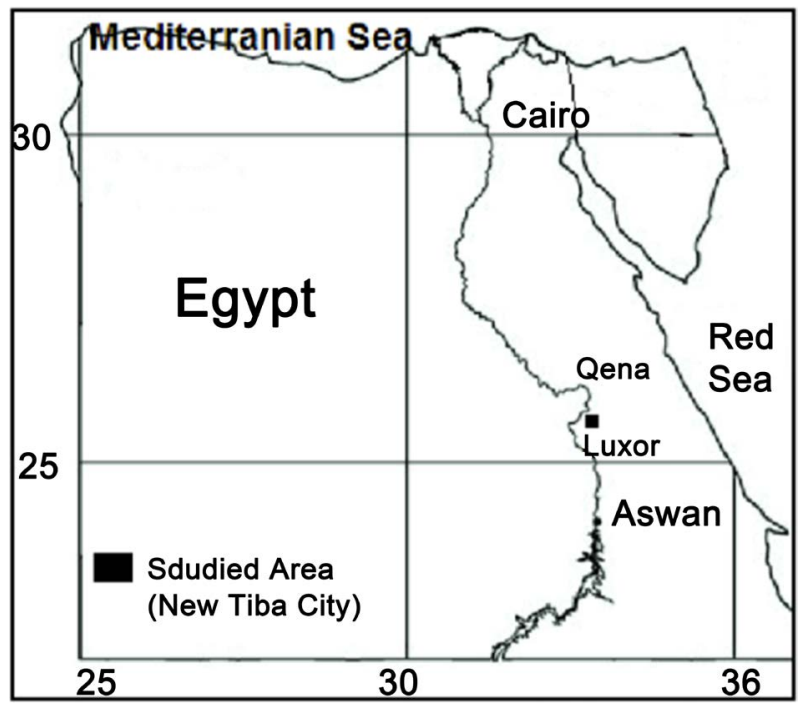

Figure 1. Location map of the studied area.

\section{$(11 \mathrm{~cm})$ Asphalt/concrete layer}

Base course layer

(15)

\section{Sub-base course layer}

\section{$(25 \mathrm{~cm})$}

Sub-grade layer

Figure 2. Typical flexible pavement structure.

Table 1. The coordinates of the studied boreholes (B1 to B6).

\begin{tabular}{ccc}
\hline Borehole (Egyptian Coordinate System) & East & North \\
\hline B1 & $790,167.046$ & $336,805.229$ \\
B3 & $789,972.716$ & $336,840.494$ \\
B4 & $789,805.070$ & $336,890.693$ \\
B5 & $790,316.516$ & $336,839.630$ \\
B6 & $790,562.020$ & $336,883.890$ \\
\hline
\end{tabular}




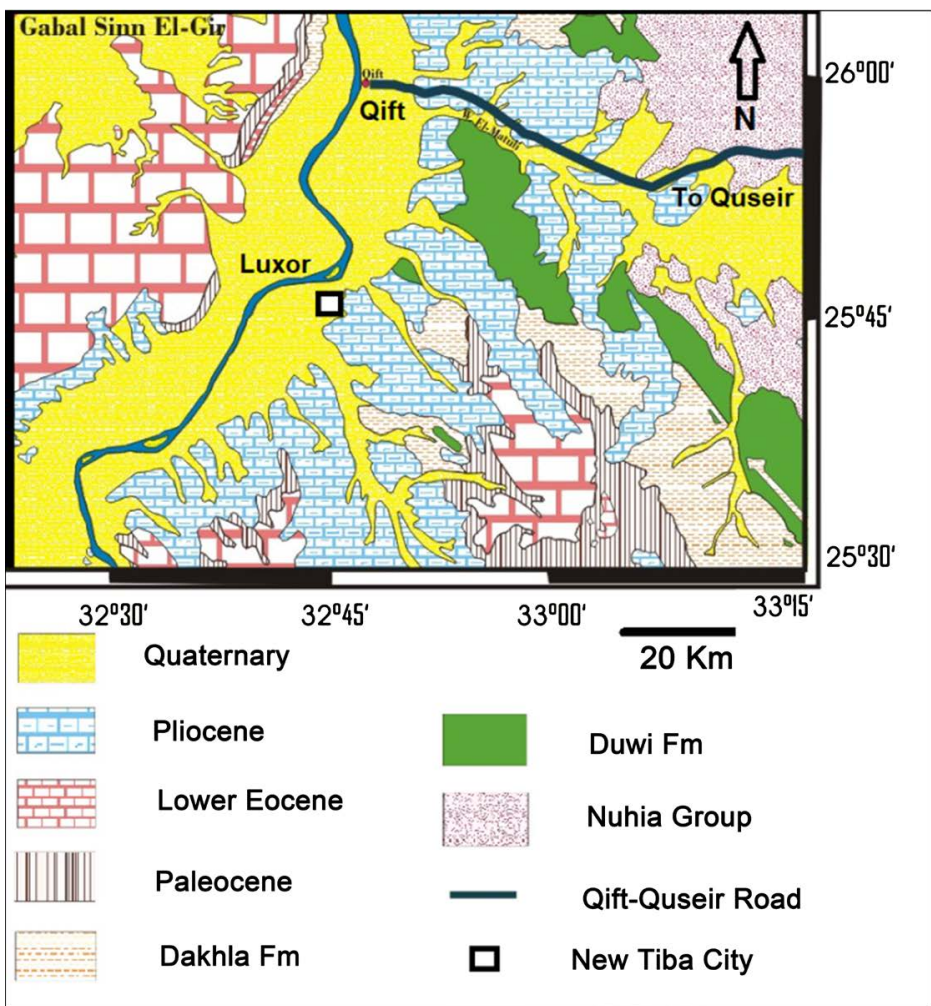

Figure 3. Geological map of the study area, modified after [22].

as well as the Pliocene-Recent sediments [15]. The surface of the study area is covered by Quaternary sediments in the form of alluvial sands, gravels, clays or mud, and Wadi deposits. The studied soils are distributed in the study area as showed in a geological map (Figure 3). The studied area is located at the border between the eastern desert and the Nile valley. The area surrounding the New Tiba city is dissected by several structurally controlled large Wadies (valleys) like Wadi Madamoud to the south of this city, Wadi Banat Biri and Wadi Khozam. The directions of these Wadis are running from the southeast to the northwest dependent the main fault trend in the area.

\section{Materials and Methods}

\subsection{Materials}

Sixty three samples were collected; sixty disturbed samples collected from six mechanical drilling boreholes, from the surface to ten meters depth including one sample each one meter depth, to carry out the grain size analyses and plasticity tests. As well as, three undisturbed samples, each sample having thirty kilometers weight, collected at $0.5 \mathrm{~m}$ depth open pits near borehole no. 2 (clayey sand sample), near borehole no. 3 (poorly graded sand sample), and near borehole no. 5 (poorly graded gravel sample). The undisturbed samples were collected to carry out the chemical and mineralogical analyses as well as free swelling, proctor, and California bearing tests. The studied soils were belonging to the Quaternary age (Table 1 and Figure 4 \& Figure 5). 


\subsection{Methods}

Six wash mechanical drilling boreholes were conducted to collect sixty studied disturbed samples (Figure 6). Three $0.5 \mathrm{~m}$ depth open pits were done to collect three undisturbed samples. Five geotechnical tests including grain size analysis [23] [24], plasticity [25], proctor [26], California bearing ration (CBR) [27] and free swelling percent [28] were carried out on the studied soils. Chemical (X-ray fluorescence, XRF, type of the instrument is JEOL, JSX 3222, Japan) and mineralogical (X-ray diffraction, XRD, PW1710 BASED diffractometer with a generator

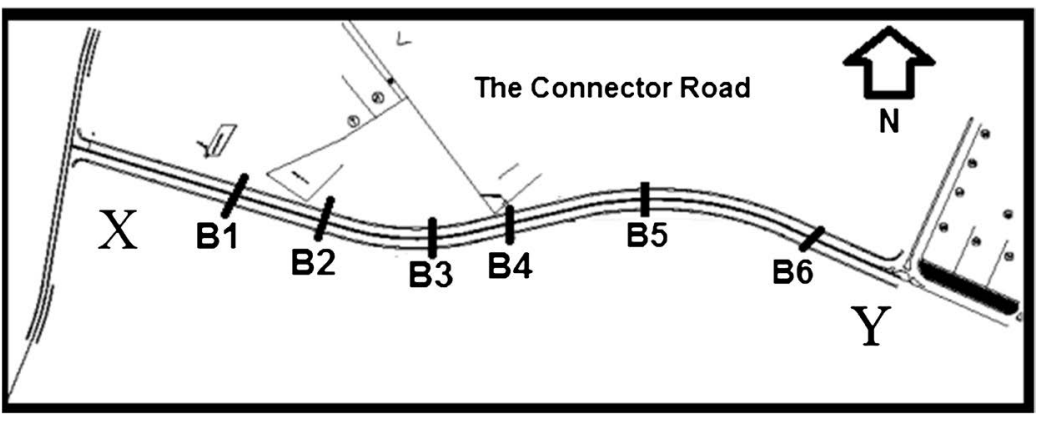

Figure 4. Layout of the connector road at the studied area, modified after layout of the connector road project.

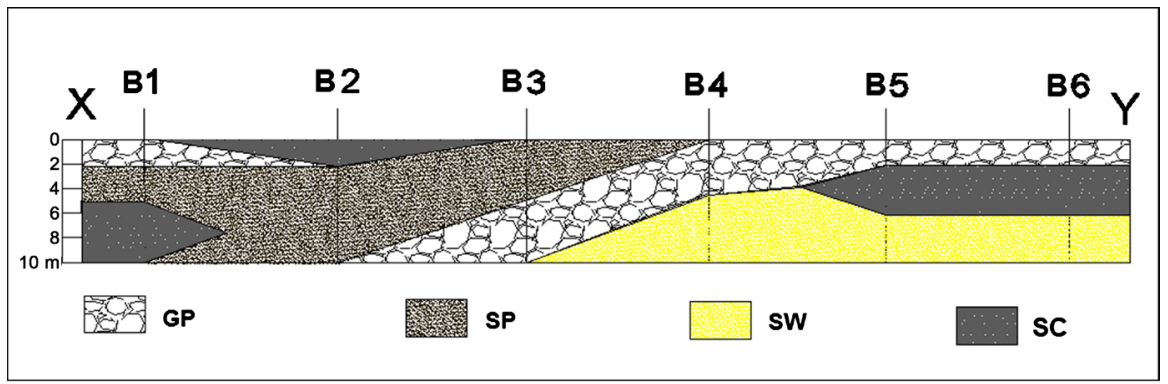

Figure 5. Vertical cross-section along the studied road area illustrates four different layers of soils; Borehole (B), poorly graded gravel (GP), poorly graded sand (SP), well graded sand (SW), and clayey sand (SC).

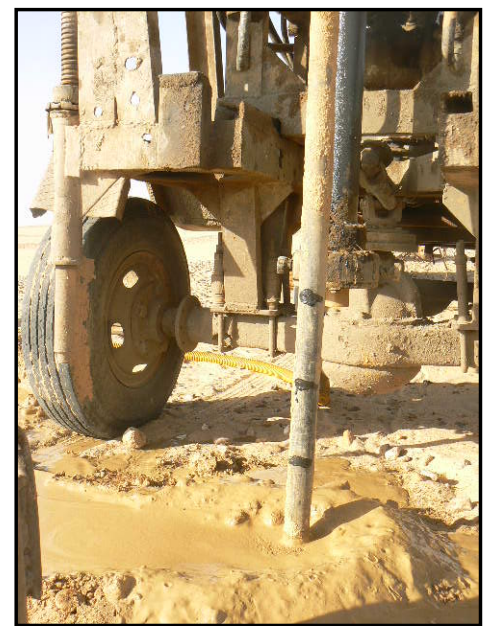

Figure 6. Wash mechanical drilling at borehole no. 5 (B5). 
operating at $40 \mathrm{KV}, 30 \mathrm{~mA}$ ) analysis of the studied clayey sand soil and some representative gravel pebbles were also applied to determine the geological origin and the sources of these gravels. Total dissolved salts, dissolved sulfate, and chloride were measured. The dissolved sulfate content was measured using Spectrophotometer (Cecil C/7400). The dissolved chlorides content was measured using the calibration method using a silver nitrate solution and potassium dichromate guide. Hydrogen ion concentration ( $\mathrm{PH}$-value), calcium carbonate, and total carbonate contents were also determined by the calibration method using sulfuric acid with phenolphthalein guide to estimate the chemical aggressiveness of the studied soils. As well as, Petrographical examination of the studied representative pebbles (gravels) using polarized light microscope was conducted to describe the lithology. The representative gravel pebbles were selected according to the difference of the lithology of the hand specimens.

\section{Results}

\subsection{Chemical, Mineralogical, and Dissolved Salts Analyses Results}

Table 2 illustrated the XRF results of the three undisturbed samples near B2, B3, and B5. XRF results pointed to that the studied Quaternary gravels were mainly composed of silica (about 68.18\%), calcium (about 13.27\%). The poorly graded sands were mainly composed of silica (85.53\%), aluminum (6.90\%). The clayey sands were mainly composed of silica (59.22\%), aluminum (10.45\%) and iron (11.60\%). The XRD results point to that the studied Quaternary gravels were composed of quartz, calcite and albite as major components and of gypsum and kaolinite as minor. The studied sands were composed of quartz, orthoclase,

Table 2. Chemical compositions of the studied undisturbed samples.

\begin{tabular}{cccc}
\hline Soil type & $\begin{array}{c}\text { Poorly gravels } \\
\text { Near B5 }\end{array}$ & $\begin{array}{c}\text { Poorly sands } \\
\text { Near B3 }\end{array}$ & $\begin{array}{c}\text { Clayey sands } \\
\text { Near B2 }\end{array}$ \\
\hline $\mathrm{Sio}_{2}$ & 68.18 & 85.53 & 59.22 \\
$\mathrm{Tio}_{2}$ & 0.35 & 0.01 & 0.80 \\
$\mathrm{Al}_{2} \mathrm{O}_{3}$ & 7.02 & 6.90 & 10.45 \\
$\mathrm{Fe}_{2} \mathrm{O}_{3}$ & 3.67 & 0.44 & 11.60 \\
$\mathrm{Mno}$ & 0.06 & 0.05 & 0.12 \\
$\mathrm{Mgo}$ & 1.22 & 0.04 & 2.44 \\
$\mathrm{CaO}$ & 13.27 & 11.27 & 6.85 \\
$\mathrm{Na}_{2} \mathrm{O}$ & 0.44 & 0.99 & 0.53 \\
$\mathrm{~K}_{2} \mathrm{O}$ & 0.73 & 0.90 & 0.80 \\
$\mathrm{P}_{2} \mathrm{O}_{3}$ & 0.19 & 0.06 & 0.11 \\
$\mathrm{Cl}$ & 0.67 & 0.22 & 0.12 \\
$\mathrm{So}_{3}$ & 1.70 & 0.93 & 1.33 \\
$\mathrm{LOI}$ & 2.50 & 2.66 & 5.63 \\
\hline & & & \\
\hline & & & 0.93 \\
\hline
\end{tabular}


albite as main components and anhydrite as traces. The results showed also that the clayey sands were composed of quartz, albite as major components and illite, montmorillonite, gypsum, and hematite as minor components. The results showed that the dissolved sulfate content of studied gravels, sands, and clayey sands is 120,85 , and $99 \mathrm{ppm}$, respectively. The dissolved chloride content is 490 , 630 , and $550 \mathrm{ppm}$, respectively.

The results also illustrated that the $\mathrm{PH}$-value of the studied gravels, sands and clayey sands is 8.4., 8.1, and 7.9, respectively. The calcium carbonate content of the studied gravels, sands, and clayey sands is $0.62,0.50$, and $0.29 \mathrm{ppm}$, respectively. The total carbonate content of the studied gravels, sands, and clayey sands is $1.05,0.88$, and $0.40 \mathrm{ppm}$, respectively. Depend on the PH-value, calcium carbonate and total carbonate contents; the chemical aggressiveness of the studied gravels, sands, and clayey sands is moderately aggressive for both gravels and sands and highly aggressive for clayey sands soils.

\subsection{Grain Size Analyses Results}

Figure 7 showed the grain size distribution curves of the studied samples. The results of the grain size distribution test of the studied soils showed that the gravel samples were classified as poorly graded gravels (GP) according to unified soil classification system (USCS) where the gradation parameters of the studied gravels including coefficient of uniformity $(\mathrm{Cu})$ were less than 4 . Sand samples especially at boreholes no. 4, 5, and 6 were classified as well graded sands (SW)

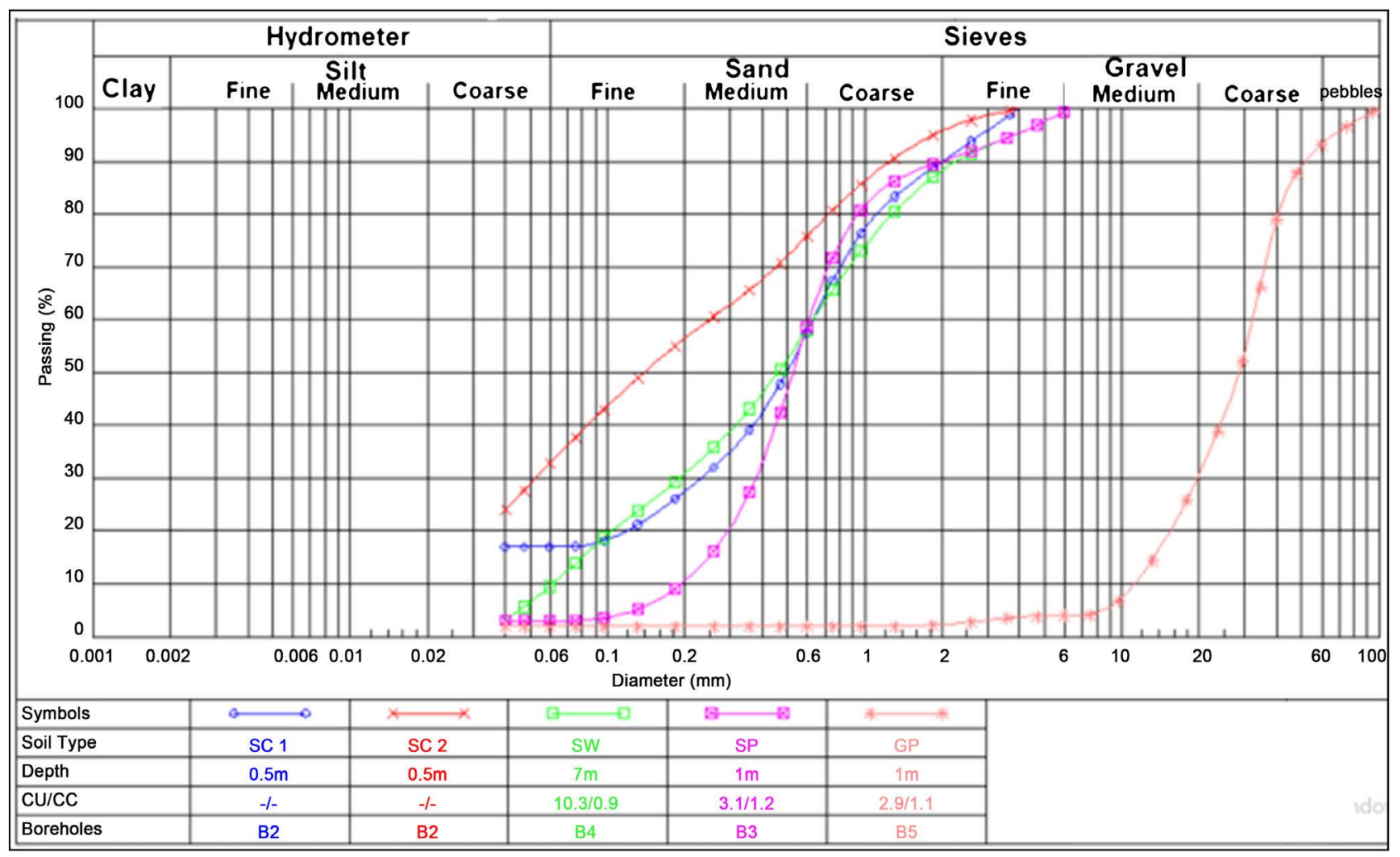

Figure 7. Grain size distribution curves of the studies samples. 
according to USCS specifications. The sands samples at borehole no. 1, 2, and 3 were classified as poorly graded sands (SP) where the gradation parameters of the studied sands including coefficient of uniformity $(\mathrm{Cu})$ were less than 6 .

The results pointed to the clayey sands samples were classified as SC according to USCS, the percent of clay was ranging from $17 \%$ to $24 \%$. According to American association of state highway and transportation official (AASHTO), SW samples were classified as A1-a group and SP samples classified as A1-b, they described as excellent to good subgrade soils. On the other hand, SC samples were classified as A2-7 group and described as fair to poor subgrade soils.

\subsection{Plasticity Test Results}

The plasticity test results showed that the plasticity index (PI), which equal to the difference between liquid limit (LL) and plasticity limit (PL), of the clayey sands samples was ranging from $15 \%$ to $17 \%$, they are medium plastic clayey sands. Liquid limit (LL) and plastic limit (PL) were ranging from $41 \%$ to $44 \%$ and from $26 \%$ to $27 \%$, respectively. The clayey sands samples described as medium plastic (Table $3 \&$ Table 4).

\subsection{Proctor Test Results}

The Modified Proctor Test was carried out to determine the maximum dry density (MDD) (Proctor density) and the optimum water content (OWC) of the studied undisturbed samples. Three selected undisturbed samples at $0.5 \mathrm{~m}$ depth were tested according to [26]. The test results are listed in Table 4.

\subsection{California Bearing Ratio Test Results}

The results of California bearing ratio (CBR) test pointed to that CBR-unsoaked

Table 3. Relation between plasticity and consistency of the soils.

\begin{tabular}{cc}
\hline Plasticity index $(\%)$ & Consistency \\
\hline$<1$ & Non plastic \\
$1-7$ & Low plastic \\
$7-17$ & Medium plastic \\
$17-35$ & High plastic \\
$>35$ & Very high plastic
\end{tabular}

Table 4. Geotechnical parameters of the studied soils.

\begin{tabular}{|c|c|c|c|c|c|c|c|c|}
\hline \multirow[t]{2}{*}{ Parameter } & \multicolumn{3}{|c|}{ Consistency Limits } & \multicolumn{2}{|c|}{ Modified Proctor } & \multirow{2}{*}{$\begin{array}{c}\text { CBR } \\
\text { Un-soaked } \\
(\%)\end{array}$} & \multirow{2}{*}{$\begin{array}{c}\text { CBR 4-days } \\
\text { Soaked } \\
(\%)\end{array}$} & \multirow{2}{*}{$\begin{array}{c}\text { Free } \\
\text { Swelling } \\
(\%)\end{array}$} \\
\hline & LL (\%) & PL (\%) & PI (\%) & $\begin{array}{l}\mathrm{MDD} \\
\mathrm{g} / \mathrm{cm}^{3}\end{array}$ & $\begin{array}{c}\text { OWC } \\
(\%)\end{array}$ & & & \\
\hline $\mathrm{SC}, \mathrm{B} 2$ & 41 & 26 & 15 & 1.82 & 14 & 14 & 7 & $30-80$ \\
\hline SC, B2 & 44 & 27 & 17 & 1.78 & 15 & 10 & 2 & $35-75$ \\
\hline SP, B3 & - & - & - & 1.91 & 12 & 79 & 55 & - \\
\hline GP, B5 & - & - & - & 2.05 & 9 & 92 & 67 & - \\
\hline
\end{tabular}


values of the investigated clayey sands soils were ranging from $10 \%$ to $14 \%$, in contrast CBR-soaked (4 days water soaking) values of these soils were ranging from $2 \%$ to $7 \%$ (Table $4 \&$ Table 5 ). The quality of the sub-grade clayey sands is described as very poor to fair according to [29].

\subsection{Free Swelling Test Results}

Free swelling test results illustrated that the free swelling percent of the studied clayey sands undisturbed samples was ranging from $30 \%$ to $80 \%$. The most tested clayey sands samples having free swelling percent more than 50\%, they are classified as low to medium expansive soils according to [28] (Table 4 \& Table 6).

\subsection{Petrographical Examination Results}

Petrographical examination of the hand specimens and some representative studied gravels pebbles under the polarized light microscope, showed that the examined pebbles were composed of igneous rocks (like granite, rhyolite, gabbro, andesite), metamorphic rocks (like gneiss), and sedimentary rocks (like crystalline limestone, organic limestone, flint, and calcareous sandstone).

\section{Conclusions and Suggestions}

\subsection{Conclusions}

The study Quaternary gravels were mainly composed of silica (about 68.18\%), and calcium (about 13.27\%). The poorly graded sands were mainly composed of silica $(85.53 \%)$ and aluminum (6.90\%). The clayey sands were mainly composed of silica $(59.22 \%)$, aluminum (10.45\%), and iron (11.60\%). The studied gravels

Table 5. Relationship between CBR-values and quality of sub-grade soils after [29].

\begin{tabular}{cc}
\hline CBR values & Quality of sub-grade soils \\
\hline $0-3$ & Very poor \\
$3-7$ & Poor to fair \\
$7-20$ & Fair \\
$20-50$ & Good \\
$>50$ & Excellent \\
\hline
\end{tabular}

Table 6. Relationship between the free swelling values and the ability of expansion after [28].

\begin{tabular}{cc}
\hline Free swelling values (\%) for soils particles passing sieve 40 & Ability of expansion \\
$30-70$ & Low expansive \\
$70-150$ & Medium expansive \\
$150-250$ & High expansive \\
$>250$ & Extreme expansive
\end{tabular}


were composed of quartz, calcite, and albite as major components and of gypsum and kaolinite as minor. The studied sands were composed of quartz, orthoclase, and albite as main components and anhydrite as traces. The clayey sands were composed of quartz, and albite as major components and illite, montmorillonite, gypsum, and hematite as minor components. The gravels pebbles were composed of igneous rocks (like granite, rhyolite, gabbro, andesite), metamorphic rocks (like gneiss), and sedimentary rocks (like crystalline limestone, organic limestone, flint, and calcareous sandstone). The minerals and chemical compositions of the studied soils in addition to the lithology pointed out that the sources of the studied gravels pebbles were the basement complexes along the red sea coast and the Upper Cretaceous-Lower Tertiary succession. A vertical cross section along the study road in $\mathrm{X}-\mathrm{Y}$ direction was achieved by a correlation between the studied six mechanical drilling boreholes data. This vertical cross section showed that the studied area along the axis of the connector road is composed of four intercalated Quaternary layers of sediments. The succession included lenses and tongues of the clayey sands, surface clayey sands lens is at borehole no. 2 . Additionally, there are two subsurface tongues of clayey sands at boreholes no. 1 ( $2 \mathrm{~m}$ depth), and at boreholes no. 5 and 6 (5 m depth). There is underground water observed until the drill depth end $(10 \mathrm{~m})$.

The gravel samples were classified as poorly graded gravels (GP) according to unified soil classification system (USCS) where the gradation parameters of the studied gravels including coefficient of uniformity $(\mathrm{Cu})$ were less than 4 . Sand samples especially at boreholes no. 4, 5, and 6 were classified as well graded sands (SW) according to USCS specifications. The sands samples at borehole no. 1,2 , and 3 were classified as poorly graded sands (SP) where the gradation parameters of the studied sands including coefficient of uniformity $(\mathrm{Cu})$ were less than 6 . The results pointed to the clayey sands samples were classified as SC according to USCS, the percent of clay particles was ranging from $17 \%$ to $24 \%$. According to American association of state highway and transportation official (AASHTO), SW samples were classified as A1-a group and both SP and GP samples classified as A1-b, they described as excellent to good sub-grade soils. On the other hand, SC samples were classified as A2-7 group and described as good to fair sub-grade soils.

The plasticity index of the clayey sands which occurred as one lens and two tongues at the studied area was ranging from $15 \%$ to $17 \%$. The clayey sands samples described as medium plastic soils. Depend on the PH-value, calcium carbonate, and total carbonate contents, the chemical aggressiveness of the studied gravels, sands, and clayey sands is moderately chemical aggressive for both gravels and sands and highly chemical aggressive for the clayey sands soils. CBR-soaked (4 day's water soaking) values of the clayey sands soils were ranging from $2 \%$ to $7 \%$. They were classified as very poor to fair sub-grade according to [29]. The free swelling percent of the studied clayey sands was ranging from 30\% to $80 \%$. Most of the studied clayey sands samples had free swelling percent more 
than $50 \%$ corresponding to [28]. They were classified as low to medium expansive soils according to [28]. The sub-grade at boreholes no. 1, 3, 4, 5, and 6 (Gravels and Sands) was good to excellent. The sub-grade at borehole no. 2 (Clayey sands) was poor to fair. The clayey sands are expansive soils and may be lead to a heave of the road at borehole no. 2. Finally, the studied clayey sands samples are problematic sub-grade soils and described as medium plastic, highly chemical aggressive and low to medium expansive soils and classified as poor to fair sub-grade soils. Finally, the present work provide that the Quaternary sediments like the present investigated soils characterized by rapid lateral and vertical changes in the lithology and texture that means each different project area in the Quaternary sediments need to a special geotechnical subsurface exploration program to investigate the Quaternary soils in details and to suggest the suitable soils reclamation and the suitable foundations design.

\subsection{Suggestions}

To avoid the engineering problems due to the problematic clayey sands sub-grade of the road especially at borehole no. 2 , one of the following treatments can be applied:

1) Replacement the expansive clayey sands sub-grade with imported well graded gravels or imported mixture of well graded gravels and sands percent ( $50 \%$ gravels plus $50 \%$ sands). The thickness of replacement must be at least 50 $\mathrm{cm}$. Compaction of the imported materials in two layers each layer has $25 \mathrm{~cm}$ thickness, until they reach to at least $97 \%$ of the modified maximum proctor density.

2) Chemical stabilization of the problematic clayey sands soil sub-grade at B2 using cement kiln dust (by-product) or mixture of cement kiln dust with lime.

3) Mechanical stabilization including compaction of the clayey sands soil sub-grade at B2 using Geotextile technique to prevent the lateral displacement of the soils especially in case of rainfall or arrival the water to the sub-grade soils.

\section{Acknowledgements}

The author is grateful for the contractor of the project, for valuable cooperation.

\section{Conflicts of Interest}

The author declares no conflicts of interest regarding the publication of this paper.

\section{References}

[1] Tensar Technical Note (TTN) (1998) Chemical and Mechanical Stabilization of Sub-Grades and Flexible Pavement Sections, BR 10.

[2] Barron, T. and Hume, W.F. (1902) Topography and Geology of the Eastern Desert of Egypt (Central Portion). Survey Department, Cairo, 331.

[3] Sandford, K.S. (1929) The Pliocene and Pleistocene Deposits of Wadi Qena and the 
Nile Valley between Luxour and Assiut, Quart. Journal of the Geological Society, 85, 493-548. https://doi.org/10.1144/GSL.JGS.1929.085.01-04.16

[4] Ball, J. (1939) Constructions to the Geography of Egypt. Survey and Mines Department, Cairo, 308.

[5] Said, R. (1961) Tectonic Framework of Egypt and Its Influence on Distribution of Foraminifera. American Association of Petroleum Geologists Bulletin, 45, 198-218.

[6] Said, R. (1962) The Geology of Egypt. Elsevier Pub. Co., Amsterdam, New York, 337.

[7] Said, R. and Sabry, H. (1964) Planktonic Foraminifera from the Type Location of Esna Shale in Egypt. Micro-Paleontology, 10, 375-395.

https://doi.org/10.2307/1484585

[8] Krasheninnikov, V.A. and Penikarov, V.P. (1964) Zonal Stratigraphy of Paleogene in the Nile Valley. Geological Survey and Mineral Resources Department, Cairo, 26.

[9] Philiobbos, E.R. (1969) Geology of the Phosphorites of the Nile Valley. Ph.D. Thesis, Assiut University, Assiut.

[10] El-Naggar, Z.R. (1970) On a Proposed Lithostratigraphic Subdivision for the Late Cretaceous-Early Paleogene Succession in the Nile Valley Egypt. 7 th Arab Petroleum Congress Kuwait, 64, 50.

[11] Said, R. (1971) Exploration Notes to Accompany the Geological Map of Egypt. Geological Survey and Mineral Resources Department, Cairo, 123.

[12] Abd El-Razik, T.M. and Razvaliaev, A.V. (1972) On the Tectonic Origin of the Nile Valley between Idfu and Qena. Egyptian Journal of Geology, 2, 235-244.

[13] Issawi, B. (1972) Review of the Upper Cretaceous-Lower Tertiary Stratigraphy in Central and Southern Egypt. American Association of Petroleum Geologists Bulletin, 55, 1448-1463.

[14] El-Etr, H.A., Yousif, M.S.M. and Dardir, A.A. (1979) Untilization of (Landsat) Images and Conventional Aerial Photographs in the Delineation of Some Aspects of Geology of Central Eastern Desert, Egypt. Annual of Geological Survey of Egypt, IX, 136-162.

[15] Abd El-Rahman, M.A. (1980) Geology of the Area Southeast of Qena with Special Reference to Phosphate Deposits. M.Sc. Thesis, Assiut University, Assiut.

[16] Ismail, I.S. (2000) Application of Geophysical Techniques for Engineering Purposes and Delineating the Underground Water at New Tiba City, Luxor, Egypt. Ph.D. Thesis, South Valley University, Egypt.

[17] Wüst, R.A.J. and McLane, J. (2000) Rock Deterioration in the Royel Tomb of Seti I, Valley of the Kings, Luxor, Egypt. Engineering Geology, 58, 163-190. https://doi.org/10.1016/S0013-7952(00)00057-0

[18] Basher, A.A. (2003) Application of Geophysical Techniques at New Qena City, Qena, Egypt. M.Sc. Thesis, South Valley University, Egypt.

[19] Ismaiel, H.A.H., Askalany, M.M. and Badry, M.M. (2011) Geotechnical Propertied and Classification of Both Non-Expansive and Expansive Soils Exposed along the New Upper Egypt-Red Sea road, Eastern Desert, Egypt. Scientific Journal of Banha University, 6, 1-18.

[20] Ismaiel, H.A.H., Makhloof, A.A., Mahmoud, A.A. and Galal, A.A. (2012) Geotechnical Behavior of Pliocene Sedimentary Rocks Exposed along Qena-Safaga Road at Qena Region, Egypt. International Journal of Mining Engineering and Mineral Processing, 1, 84-93. https://doi.org/10.5923/j.mining.20120102.10 
[21] Ismaiel, H.A.H. (2013) Geotechnical Evaluation of Sub-Grade Soils at the Cemeteries Area, New Tiba City, Luxor, Egypt. Geosciences, 3, 53-59.

[22] Egyptian Geological Survey and Minning Authority (1978) Geological Map of Qena Quadrangle, Egypt, Scale 1:500,000.

[23] AASHTO, T27 (2010) Standard Method of Test for Sieve Analysis of Fine and Coarse Aggregates, Single User Digital Publication. American Association of State Highway and Transportation Officials, Washington DC.

[24] AASHTO, T88 (2010) Standard Method of Test for Particle Size Analysis of Soils, Single User Digital Publication. American Association of State Highway and Transportation Officials, Washington DC.

[25] AASHTO, T90 (2010) Standard Method of Test for Determining the Plastic Limit and Plasticity Index of Soils, Single User Digital Publication. 20th Edition, American Association of State Highway and Transportation Officials, Washington DC.

[26] AASHTO, T99 (2010) Standard Method of Test for Moisture-Density Relations of Soils Using a $2.5 \mathrm{~kg}$ (5.5-lb) Rammer and a 305-mm (12-in.) Drop, Single User Digital Publication. American Association of State Highway and Transportation Officials, Washington DC.

[27] AASHTO, T193 (2010) Standard Method of Test for the California Bearing Ratio, Single User Digital Publication. American Association of State Highway and Transportation Officials, Washington DC.

[28] Egyptian Code (2001) Egyptian Code of Soil Mechanics, Foundations Carrying out and Designation, Part 2, Laboratory Tests. 6th Edition, 314.

[29] Bowles, J. (1992) Engineering Properties of Soil and Their Measurements. 4th Edition, McGraw-Hill, Boston. 